\title{
School-leavers between education and the labour market 2015. Facts and figures
}

Citation for published version (APA):

Meng, C. M., \& Sijbers, E. (2016). School-leavers between education and the labour market 2015. Facts and figures. ROA. ROA Fact Sheets No. 002E https://doi.org/10.26481/umarof.2016002E

Document status and date:

Published: 01/01/2016

DOI:

10.26481/umarof.2016002E

Document Version:

Publisher's PDF, also known as Version of record

\section{Please check the document version of this publication:}

- A submitted manuscript is the version of the article upon submission and before peer-review. There can be important differences between the submitted version and the official published version of record.

People interested in the research are advised to contact the author for the final version of the publication, or visit the DOI to the publisher's website.

- The final author version and the galley proof are versions of the publication after peer review.

- The final published version features the final layout of the paper including the volume, issue and page numbers.

Link to publication

\footnotetext{
General rights rights.

- You may freely distribute the URL identifying the publication in the public portal. please follow below link for the End User Agreement:

www.umlib.nl/taverne-license

Take down policy

If you believe that this document breaches copyright please contact us at:

repository@maastrichtuniversity.nl

providing details and we will investigate your claim.
}

Copyright and moral rights for the publications made accessible in the public portal are retained by the authors and/or other copyright owners and it is a condition of accessing publications that users recognise and abide by the legal requirements associated with these

- Users may download and print one copy of any publication from the public portal for the purpose of private study or research.

- You may not further distribute the material or use it for any profit-making activity or commercial gain

If the publication is distributed under the terms of Article $25 \mathrm{fa}$ of the Dutch Copyright Act, indicated by the "Taverne" license above, 
Dus Maastricht University in Learning!

Research Centre for Education and the Labour Market | ROA

\section{School-leavers between education and the labour market 2015 \\ Facts and figures}

\section{ROA Fact Sheet}

ROA-F-2016/2E

Researchcentrum voor Onderwijs en Arbeidsmarkt | ROA Research Centre For Education and the Labour Market / ROA 


\section{Introduction}

Every year, ROA carries out a survey among school-leavers on the transition from school to the labour market or to subsequent education programmes. This fact sheet presents the results of the survey completed by ROA at the end of 2015 among graduates from the 20I3-20I4 school year, so approximately eighteen months after graduation. For the full results, please refer to the ROA report "School-leavers between education and the labour market 2015". A total of 2I2,II7 school-leavers and graduates were approached. The total response rate was $24 \%$.

The results cover almost the entire educational spectrum in the Netherlands: Preparatory Secondary Vocational Education (PSVE), Secondary Vocational Education School-based Route (SVE-VT), Secondary Vocational Education - Work-based Route (SVE-DR), Senior General Secondary Education (SGSE), Pre-University Education (PUE) and Higher Vocational Education (HVE). Within SVE, a distinction is made between, on the one hand, two different learning routes (VT and DR) and on the other hand within each learning route between 4 levels. The data in the fact sheet have been aggregated across the education sectors, but the appendix also provides an overview of the figures for each education level differentiated by type of education. For reasons of comparability, the results for HVE only relate to graduates from full-time programmes.

The results from the survey among school-leavers and graduates must be seen within the wider context of the economic situation. The transition from education to the labour market is always determined partly by the current situation. The global financial crisis, followed by a debt crisis in the eurozone, has had its impact on the labour market. The influence of the economic situation applies not only to the indicators that are directly related to labour market entry (e.g. unemployment or tenure), but may also affect the way in which youngsters assess the education programmes completed. Readers should bear this in mind.

\section{Preparation for the labour market}

Intermediate and higher vocational education programmes should prepare youngsters for a position in the labour market. ${ }^{I}$ Education should also provide a basis for further development of knowledge and skills, both in professional careers and in any subsequent education. Table I shows the percentage of graduates who feel that the course that they completed, provides a good or very good basis for a start on the labour market. It also shows the percentage of graduates who feel that the course that they had completed provided a good or very good basis for further development.

Of all SVE graduates, a total of $6 \mathrm{I} \%$ feel that their education programme provides a good basis for further develop-

I Exceptions are SVE Level I courses, which formally do not provide a basic qualification. ment of their knowledge and skills, against $47 \%$ who think that the programme is a good basis for labour market entry. A notable fact within SVE is that the DR programmes score better as a basis for labour market entry (55\%) than the VT programmes $(43 \%)$. As SVE-DR courses contain many more hours of practical work experience than SVE-VT courses, it is not surprising that graduates from SVE-DR courses feel better prepared for the labour market. However, SVE-DR courses also score better when it comes to providing a basis for further development of knowledge and skills (65\%) than SVE-VT courses (59\%). Within SVE-VT, Level 2 programmes score best on both items, whereas within SVE-DR this applies to Level 3 programmes.

Of all HVE graduates, a total of $64 \%$ feel that their education programme provides a good basis for further development of their knowledge and skills, against $49 \%$ who think that the programme is a good basis for labour market entry.

Table 1

Education programme as preparation for the labour market and further development of knowledge and skills (\%)

\begin{tabular}{l|c|c|} 
& Labour market entry & $\begin{array}{c}\text { Further development of } \\
\text { knowledge and skills } \\
\text { Good/very good basis (\%) }\end{array}$ \\
\hline SVE-VT 1 & 38 & 56 \\
\hline SVE-VT 2 & 44 & 60 \\
\hline SVE-VT 3 & 44 & 59 \\
\hline SVE-VT 4 & 42 & 58 \\
\hline SVE-DR 1 & 34 & 47 \\
\hline SVE-DR 2 & 48 & 58 \\
\hline SVE-DR 3 & 62 & 71 \\
\hline SVE-DR 4 & 62 & 70 \\
\hline HVE & 49 & 64
\end{tabular}

\section{Success in the labour market}

The returns of an education programme in economic terms depend on a number of factors at the time of labour market entry. The labour market entry of graduates from SVE and HVE has therefore been analysed on the basis of various indicators.

Figure I shows the employment rates at the time of survey for the various types of courses between 2002 and 2015. The impact of economic trends on employment rates is clearly visible in the figure. Both the economic crisis of 2002-2005 and the economic crisis that started in 2009 are reflected by rising unemployment rates. Between 2008 and 20I4, the effect of the most recent crisis has been that the unemployment figures for SVE-VT graduates have tripled (from $4 \%$ in 2008 to almost $13 \%$ in 20I4); for SVE-DR graduates, they even sextupled (from I\% in 2008 to $6 \%$ in 20I4), while for HVE graduates, the unemployment rate more than doubled (from $3 \%$ in 2008 to $7 \%$ in 20I4). Although there was already a slight decline in unemployment among HVE graduates in 2014 (-0,7 percentage points), 2015 showed a

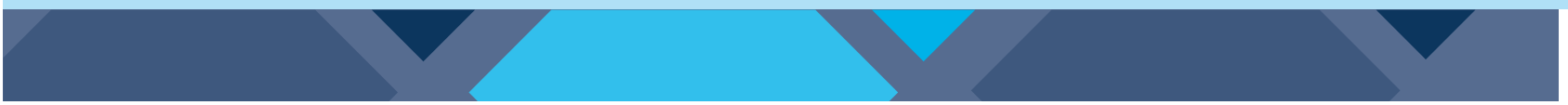


strong decline in the unemployment figures. For SVE-VT graduates, the unemployment rate dropped by I. 8 percentage points to $11 \%$, for SVE-DR graduates it even dropped by 2.2 percentage points to $4 \%$, and for HVE graduates it went down by $\mathrm{I} .3$ percentage points to $6 \%$.

Figure 1

Unemployment at the time of the survey (\%)

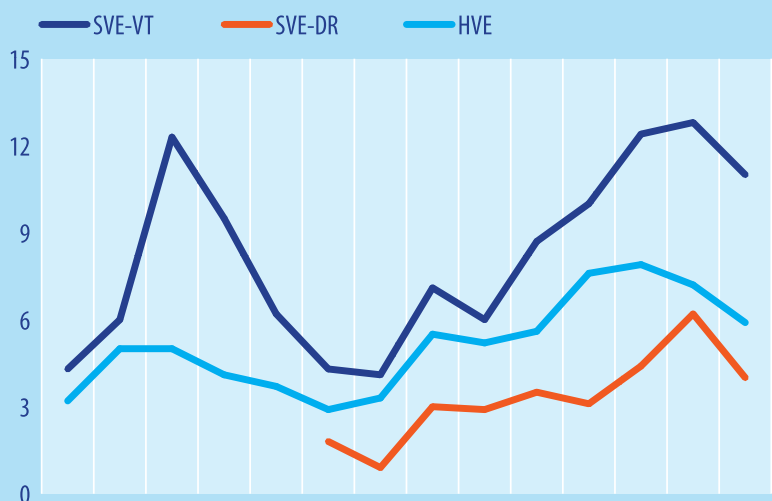

20022003200420052006200720082009201020112012201320142015

However, the unemployment rate at the time of the survey is not the only indicator of the smoothness of labour market entry. Figure 2 therefore also includes data relating to the duration of the search for the first job.

We can see that it takes longer for graduates from SVE-VT programmes to find their first job than for graduates from SVE-DR programmes. On average across all four education levels, $20 \%$ of the SVE-VT graduates experienced entry unemployment, against $9 \%$ of the SVE-DR graduates. These result are possibly due to the fact that DR graduates often find a job in the company in which they did their training.

There is also a difference between the various levels within SVE programmes when it comes to the time it takes to find the first job. Generally, the higher the level of the programme, the greater the chance of finding a job without entry unemployment. Within SVE-VT programmes, graduates from Level I suffer most from entry unemployment $(26 \%$, of whom 17 percentage points are unemployed for more than 3 months) $)^{2}$, followed by Level 2 (24\%, I7 percentage points longer than 3 months), Level 3 (21\%, I2 percentage points longer than 3 months), and Level 4 (I $8 \%$, where even II percentage points takes longer than 3 months). Within SVE-DR programmes, graduates from Level 2 suffer most from entry unemployment ( $13 \%$, of whom 7 percentage points are unemployed for more than 3 months), followed by Level I (Iо\%, 7 percentage points longer than 3 months), Level 3 ( $8 \%$, 4 percentage points longer than 3 months), and Level 4 ( $7 \%$, 3 percentage points takes longer than 3 months).

Figure 2 also shows that graduates from HVE suffered comparatively most from entry unemployment. No less than $32 \%$ of the HVE graduates experienced entry unemployment, against I $6 \%$ of the SVE graduates. Of them, I4\% looked for I to 3 months before finding their first job, I3\% took 4 to I2 months, and 5\% even took I3 months or more. A possible explanation for the high entry unemployment rate among HVE graduates is the fact that they are more selective when they look for a job and have a more explicit desire to find a job that matches the level and type of course that they have completed than SVE graduates.

Figure 2

Entry unemployment (\%)

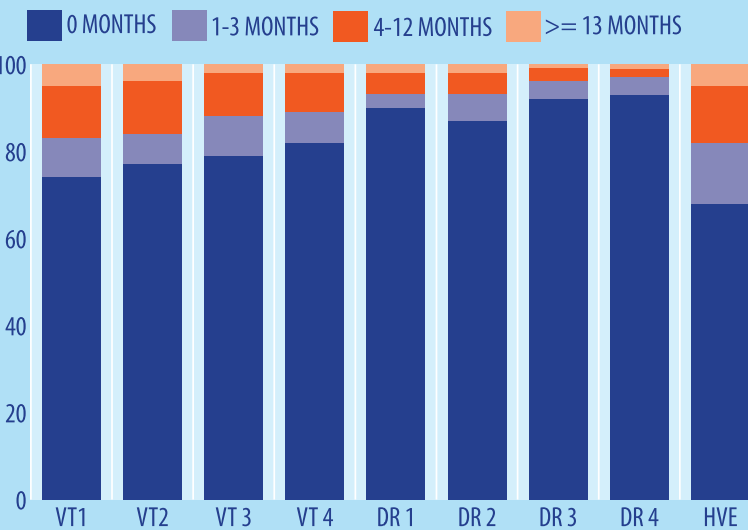

In addition to unemployment rates, there are some other important indicators that illustrate the match between education and the labour market. Figure 3 shows how well the school-leavers' jobs match the programmes that they completed in terms of level and type of education. Among the SVE graduates, $7 \mathrm{I} \%$ find a job that is at least at the level of the education programme completed, with DR graduates doing slightly better ( $72 \%)$ than VT graduates (71\%). At $\mathrm{HVE}$, on average $77 \%$ have a job that at least matches their education level.

In addition to the level of the job, the type of job is also an important factor in determining the quality of employment. Figure 3 shows that school-leavers with a diploma from the lowest level within SVE are the least likely to work within their own occupational domain. The most likely ones to be working within their own occupational domain, are graduates from Level 4 ( $74 \%$ for VT Level 4 and $85 \%$ for DR Level 4). Of all HVE graduates, $77 \%$ work in their own or a related domain. 
Figure 3

Match between job and education programme completed

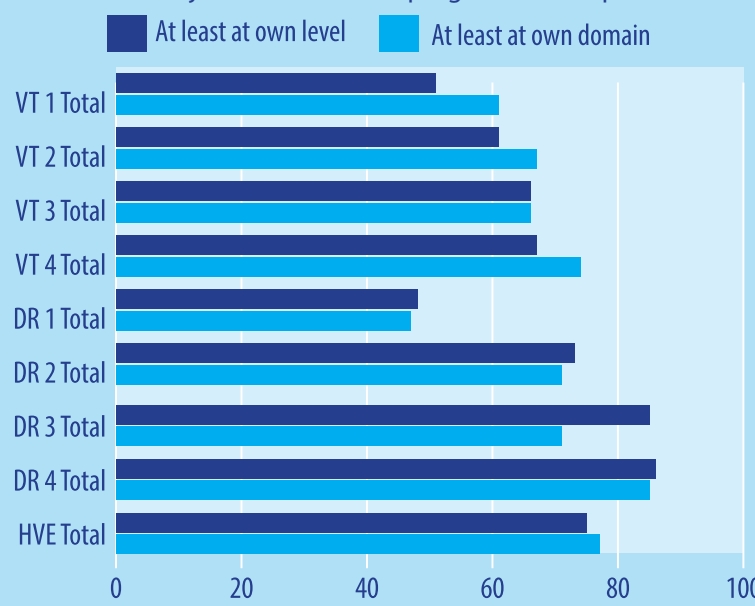

Complementary to these objective indicators, the match between education and the labour market has also been analysed in a more subjective way, by asking respondents how satisfied they themselves were with the match between their job and the course that they had completed.

On the whole, we can state that SVE-DR graduates are more satisfied with this than SVE-VT graduates. In SVE-DR, $83 \%$ of the graduates find the match sufficient to good, while for SVE-VT, this applies to 68\%. HVE graduates are slightly above SVE-VT: $72 \%$ find the match sufficient or good.

Figure 4

Match between programme completed and current job (\%)

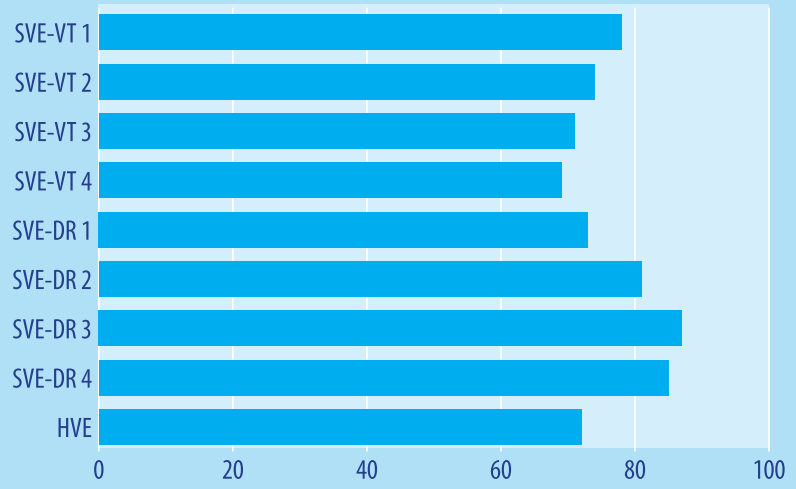

Another indicator for the quality of work and the transition from education to the labour market, is the wages received by working school-leavers. Table 2 shows for each education level the average gross hourly wages. Hourly wages allow a better comparison than monthly wages, as differences in monthly wages can also be caused by the number of hours worked.

For both SVE-VT and SVE-DR, the higher the education level acquired, generally the higher the hourly wages are. On average, the hourly wages for SVE-VT graduates is lower (€9.08) than the hourly wages of SVE-DR graduates (€II.97). Among VT graduates, gross hourly wages vary from $€ 6.39$ (Level I) to $€ 9.82$ (Level 4 ), while DR gradu- ates earn between $€ \mathrm{IO} .25$ (Level I) and $€ \mathrm{I} 3.94$ (Level 4). The average hourly wages for HVE graduates is higher (€I3.3I) than those for SVE-VT or SVE-DR graduates. The only underlying exception is that graduates from SVE-DR Level 4 earn higher hourly wages $\left(€_{\mathrm{I} 3.94)}\right)$ than HVE graduates (€I3.3I).

\begin{tabular}{|l|r|}
\hline Table 2 & \\
\hline Average gross hourly wages $(€)$ & uurloon \\
\hline & 6,39 \\
\hline SVE-VT 1 & 7,47 \\
\hline SVE-VT 2 & 9,04 \\
SVE-VT 3 & 9,82 \\
SVE-VT 4 & 10,26 \\
SVE-DR 1 & 10,36 \\
SVE-DR2 & 12,51 \\
SVE-DR 3 & 13,94 \\
SVE-DR 4 & 13,31 \\
\hline HVE & \\
\hline Hourly wages rounded to nearest 5 eurocent &
\end{tabular}

\section{Level of job satisfaction}

Although all aspects discussed are key indicators for the success of a programme and the entry qualification, the satisfaction of school-leavers with their current jobs is perhaps the most important issue. The level of satisfaction is measured using two indicators: the overall satisfaction with the current job, and the level of satisfaction with the career perspectives offered by that job. Table 3 shows for each education level how satisfied graduates are with their current jobs and with the career perspectives offered by those jobs.

On the whole, HVE graduates are the most satisfied ones with their current jobs: Two thirds $(66 \%)$ is satisfied with his or her current job, while another $57 \%$ feels that his or her current job offers good career perspectives. Within SVE, DR graduates are slightly more satisfied with their current jobs (68\%) than VT graduates (66\%). Graduates from Level I programmes are the least satisfied with their current jobs, both in SVE-VT (6I\%) and SVE-DR (58\%).

Table 3

Level of satisfaction with current job and career perspectives (\%)

\begin{tabular}{|l|r|r|r|r|r|r|r|r|r|}
\hline & VT 1 & VT 2 & VT 3 & VT 4 & DR 1 & DR 2 & DR 3 & DR 4 & HVE \\
\hline $\begin{array}{l}\text { Satisfied with job } \\
\begin{array}{l}\text { Good career } \\
\text { perspectives }\end{array}\end{array}$ & 61 & 66 & 65 & 66 & 58 & 68 & 70 & 70 & 66 \\
\hline
\end{tabular}

\section{Transition to further education}

After graduation, youngsters may choose to continue their educational career instead of entering the labour market. Figure 5 gives an overview of the qualifying follow-up routes for the graduates from this survey. 
Moving on to further education decreases as the level of the diploma acquired is higher. PSVE is not regarded as a basic qualification and this is confirmed by the rate of graduates moving on to further education (97\%). Most of these move on to SVE-VT programmes (75\%), while some move on to SVE-DR programmes (I2\%). Another part (9\%) moves on to SGSE. Having graduated from an SVE-VT programme, $57 \%$ opt for a follow-up course. 30 percentage points go to an HVE programme, 22 percentage points to another SVE-VT programme, while $5 \%$ choose an SVE-DR programme. From SVE-DR, fewer graduates opt for further education than from SVE-VT, but the figure is still $22 \%$. Most of them opt for another SVE-DR programme (I5\%), but 3\% choose an SVE-VT programme, while another 3\% move on to an HVE programme.

From SGSE, 92\% take a follow-up course. The majority of them choose an HVE course to continue their education $(85 \%)$, but $4 \%$ opts for an SVE-VT course, while I\% continue in PUE. From PUE, 96\% take a follow-up course. Most of them choose a UE programme (80\%), but a number of them opt for an HVE programme (I5\%). The graduates from SGSE and PUE who do not move on to further education, usually leave the education system only temporarily, as many of them take a sabbatical year to travel, or have other plans before starting their next course.

From HVE, about a quarter (25\%) decides to take another course. Most of them choose a UE programme (I6\%), but the option of another HVE programme also occurs (5\%).

\section{Figure 5}

Educational follow-up routes after graduation

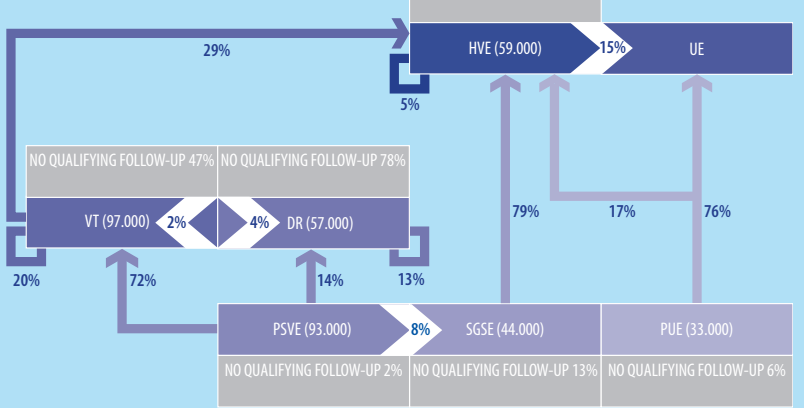

School-leavers who had moved on to a subsequent education programme, were asked what they thought of the match between the programme that they had completed and the subsequent one. Figure 6 shows which part of the school-leavers who continued their studies considered this match sufficient or good. The vast majority of those who moved on to a subsequent programme $(77 \%)$ thought that the match between their previously completed programme and the subsequent one was sufficient to good.

In secondary education, PUE graduates value their courses best $(85 \%$ is satisfied), while PSVE graduates are the least satisfied with the match ( $78 \%$ is satisfied). As PSVE does not provide a basic qualification and a subsequent course is a logical next step, the match between PSVE and follow-up education should not have any shortcomings.

Within SVE, we see that SVE-VT graduates on the whole are more critical of the match than SVE-DR graduates. Across all levels, $82 \%$ of all SVE-DR graduates and $70 \%$ of the SVE-VT graduates find the match sufficient. A notable fact within SVE is that the higher levels are less satisfied with the match than the lower levels. Whereas $80 \%$ of those from Level I (SVE-DR I) and 88\% (SVE-VT I) are satisfied, at level 4 this only applies to $66 \%$ (SVE-DR 4 ) and $60 \%$ (SVE-VT 4). It needs to be taken into account that school-leavers with a diploma from the lower level SVE-VT programmes usually move on to subsequent programmes within SVE, while for qualified school-leavers from SVE Level 4, continuing their education generally means switching to HVE.

Of the HVE graduates, $73 \%$ is satisfied with the match with subsequent education, which ranks HVE between SVE-VT (70\%) and SVE-DR (82\%).

Figure 6

Match between programme completed and subsequent programme (\%)

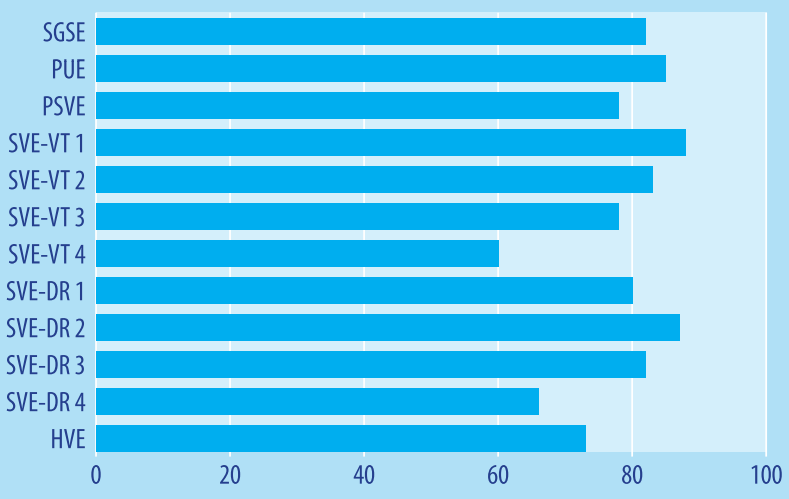

For more insight in the success of subsequent courses, Figure 7 shows the percentage of youngsters who had left their follow-up course at the time of the survey (approximately eighteen months after graduation). A distinction is made between programme switchers (who stopped a programme, but immediately started another one) and dropouts (who had left the education system).

Of all secondary-school graduates who started a new course, most programme switchers can be found in SGSE ( $2 \%$ ), followed by PUE (7\%) and PSVE (4\%). Most dropouts in secondary education can be found in SGSE who went on to do a follow-up course (3\%), followed by PSVE graduates (2\%) and PUE graduates (I\%).

Among graduates from SVE, the group from SVE-VT who went on to do another course shows more programme switchers than the group of SVE-DR graduates. Among the SVE-VT graduates who went on to do another course, $4 \%$ switches programmes, while the figure is (almost) nil (o\%) for SVE-DR graduates. The dropout rate is also higher among SVE-VT graduates (6\%) than among SVE-DR graduates $(4 \%)$. Among HVE graduates who went on to 
do another course, the dropout rate is $5 \%$, while there are (almost) no programme switchers (o\%).

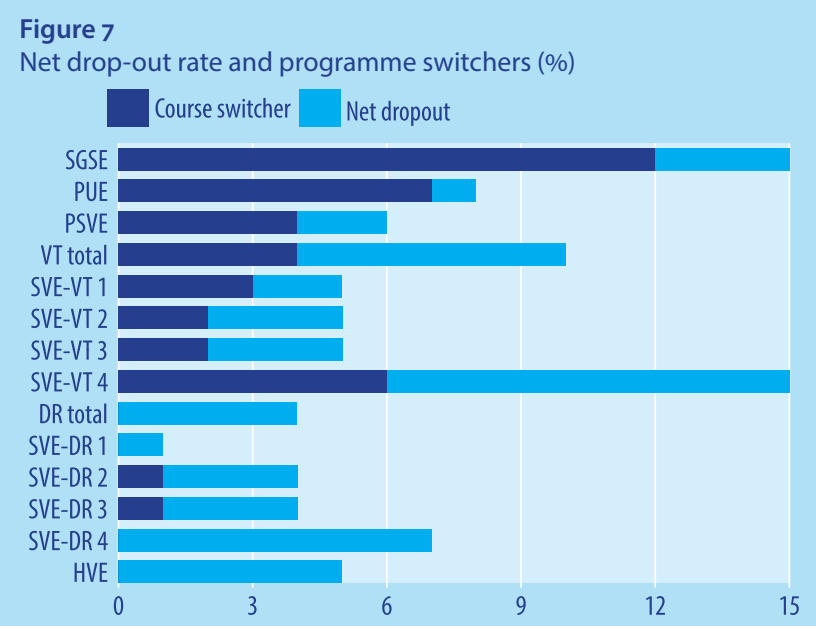

\section{Satisfaction with education programme}

Various indicators were used to measure the level of satisfaction of school-leavers with the education programme completed. The survey looked both at education-specific issues (such as the content of the programmes, teaching methods, etc.) and more material and practical aspects (such as facilities).

As a concluding assessment, graduates were asked whether - looking back - they would choose the same education programme again (see Table 4). Of all graduates, $82 \%$ would choose the same programme again. This percentage shows that a large majority of the respondents still agree with the choice made with respect to the education programme. The highest score is obtained in GSE, where no less than $98 \%$ would choose the same programme again.
Within SVE, SVE-DR graduates are satisfied with their course relatively more often than SVE-VT graduates Across all levels together, $84 \%$ of all SVE-DR graduates would choose the same course again, against $76 \%$ of all SVE-VT graduates. Within SVE, graduates from the higher levels, when looking back, are satisfied with their choice relatively more often than graduates from the lower levels. At Level 4 , $78 \%$ of SVE-VT graduates and $85 \%$ of SVE-DR graduates are satisfied, while at Level I this applies to $7 \mathrm{I} \%$ (SVE-VT) and $76 \%$ (SVE-DR). More than three quarters of all HVE graduates are satisfied with the course that they had chosen: $78 \%$ would choose the same course again.

Table 4

Level of satisfaction looking back (\%)

\begin{tabular}{|l|r|r|}
\hline & \multicolumn{2}{|c|}{$\begin{array}{c}\text { Choice of programme } \\
\text { Same programme }\end{array}$} \\
\hline SGSE/PUE & 98 & 2 \\
\hline PSVE & & Different programme \\
\hline SVE-VT 1 & 87 & 13 \\
\hline SVE-VT 2 & & \\
\hline SVE-VT 3 & 71 & 29 \\
\hline SVE-VT 4 & 73 & 27 \\
\hline SVE-DR 1 & 75 & 25 \\
\hline SVE-DR 2 & 78 & 22 \\
\hline SVE-DR 3 & & \\
\hline SVE-DR 4 & 76 & 24 \\
\hline HVE & 82 & 18 \\
\hline Total & 86 & 14 \\
\hline
\end{tabular}




\section{General}

Course provides a good basis for labour market entry (\%)
Course provides a good basis for further development of knowledge and skills (\%)
Looking back, choose course again (\%)

PSVE

PSVE theoretical programme

PSVE Agriculture

PSVE Technology

PSVE Economics

PSVE Health Care

PSVE intersectoral

SVE

VT 1

VT 2

VT 2 Agriculture

VT 2 Technology

VT 2 Economics

VT 2 Health Care

VT 3

VT 3 Agriculture

VT 3 Technology

VT 3 Economics

VT 3 Health Care

VT 3 Behaviour \& Society

VT 4

VT 4 Agriculture

VT 4 Technology

VT 4 Economics

VT 4 Health Care

VT 4 Behaviour \& Society

DR

DR 1

DR 2

DR 2 Agriculture

DR 2 Technology

DR 2 Economics

DR 2 Health Care

DR 3

DR 3 Agriculture

DR 3 Technology

DR 3 Economics

DR 3 Health Care

DR 3 Behaviour \& Society
47

43

38

27
22
26
33
39
34
20

44

47

46

44

41

$44 \quad 5$

$49-57$

51

39

54

40

$42 \quad 58$

44

44

48

38

52

34

55

34

48

42

50

47

44

62

57

62

48

75

53

61

59

56

$\begin{array}{ll}57 & 87 \\ 59 & 88 \\ 53 & 88 \\ 60 & 81 \\ 61 & 85 \\ 59 & 89 \\ 45 & 88\end{array}$

71

73

80

78

70

71

75

78

80

70

80

74

78

78

83

76

84

76

84

85

78

78

86
88
88
79
88
84

6

82

87

81

5

88

79

76

1

3
8
8
1

75
78
70
80
74

78
71
9
78
83
76

84




\section{General}

Course provides a good basis for labour market entry (\%)
Course provides a good basis for further development of knowledge and skills (\%)
Looking back, choose course again (\%)

85

$\begin{array}{ll}70 & 85 \\ 59 & 71 \\ 74 & 86 \\ 61 & 82 \\ 77 & 89 \\ 61 & 76\end{array}$

46

65

52

70

48

HVE

HVE Agriculture

HVE Technology

HVE Economics

HVE Health Care

HVE Behaviour \& Society

HVE Education

HVE Language \& Culture

Total

Source: ROA (SIS)

$\begin{array}{lll}49 & 64 & 78 \\ 59 & 70 & 77 \\ 60 & 68 & 84 \\ 50 & 63 & 72 \\ 52 & 67 & 84 \\ 38 & 61 & 74 \\ 54 & 60 & 86 \\ 29 & 71 & 84 \\ 41 & & 82\end{array}$




\section{Subsequent education}

\begin{tabular}{|c|c|c|c|}
\hline & $\begin{array}{c}\text { match } \\
\text { reasonable/good (\%) }\end{array}$ & $\begin{array}{c}\text { net dropout } \\
\text { in subsequent course (\%) }\end{array}$ & $\begin{array}{c}\text { Course switcher } \\
\text { in subseuqnent education (\%) }\end{array}$ \\
\hline SGSE/PUE & 83 & 2 & 10 \\
\hline SGSE & 82 & 3 & 12 \\
\hline PUE & 85 & 1 & 7 \\
\hline PSVE & 78 & 2 & 4 \\
\hline PSVE theoretical programme & 78 & 0 & 5 \\
\hline PSVE Agriculture & 77 & 3 & 4 \\
\hline PSVE Technology & 73 & 0 & 3 \\
\hline PSVE Economics & 78 & 6 & 1 \\
\hline PSVE Health Care & 72 & 4 & 5 \\
\hline PSVE intersectoral & 78 & 5 & 7 \\
\hline SVE & 72 & 6 & 3 \\
\hline VT & 70 & 6 & 4 \\
\hline VT 1 & 88 & 2 & 3 \\
\hline VT 2 & 83 & 3 & 2 \\
\hline VT 2 Agriculture & 77 & 2 & 2 \\
\hline VT 2 Technology & 83 & 2 & 2 \\
\hline VT 2 Economics & 81 & 3 & 1 \\
\hline VT 2 Health Care & 87 & 4 & 2 \\
\hline VT 3 & 78 & 3 & 2 \\
\hline VT 3 Agriculture & 74 & 7 & 2 \\
\hline VT 3 Technology & 78 & 6 & 1 \\
\hline VT 3 Economics & 77 & 3 & 2 \\
\hline VT 3 Health Care & 81 & 3 & 1 \\
\hline VT 3 Behaviour \& Society & 75 & 4 & 1 \\
\hline VT 4 & 60 & 8 & 6 \\
\hline VT 4 Agriculture & 53 & 9 & 4 \\
\hline VT 4 Technology & 61 & 9 & 4 \\
\hline VT 4 Economics & 61 & 9 & 7 \\
\hline VT 4 Health Care & 62 & 8 & 3 \\
\hline VT 4 Behaviour \& Society & 57 & 8 & 6 \\
\hline DR & 82 & 4 & 0 \\
\hline DR 1 & 80 & 1 & 0 \\
\hline DR 2 & 87 & 3 & 1 \\
\hline DR 3 & 82 & 3 & 1 \\
\hline DR 4 & 66 & 7 & 0 \\
\hline
\end{tabular}




\section{Subsequent education}

match

net dropout

Course switcher

reasonable/good (\%)

in subsequent course (\%)

in subseuqnent education (\%)

HVE

73
72

HVE Agriculture

HVE Technology

HVE Economics

HVE Health Care

HVE Behaviour \& Society

HVE Education

72

70

72

72
77

73

HVE Language \& Culture

80

Total

6
5
8
7
5
8
3
5

1

0

8

0

- 0

5 - 0

Source: ROA (SIS) 


\section{Labour market}

\begin{tabular}{|c|c|c|c|c|c|c|}
\hline & $\begin{array}{l}\text { At least at own level } \\
\text { (\%) }\end{array}$ & $\begin{array}{c}\text { Own/related domain } \\
(\%)\end{array}$ & $\begin{array}{l}\text { Match sufficient/ } \\
\operatorname{good}(\%)\end{array}$ & $\begin{array}{l}\text { Unemployed } \\
(\%)\end{array}$ & $\begin{array}{c}\text { Entry unemployment } \\
>3 \text { months }(\%)\end{array}$ & $\begin{array}{l}\text { Gross hourly wages } \\
\text { (euro) }\end{array}$ \\
\hline SVE & 71 & 28 & 77 & 8 & 9 & 10,49 \\
\hline VT & 71 & 35 & 70 & 11 & 13 & 9,08 \\
\hline VT 1 & 61 & 49 & 78 & 30 & 17 & 6,39 \\
\hline VT 2 & 67 & 61 & 74 & 16 & 17 & 7,47 \\
\hline VT 2 Agriculture & 62 & 54 & 76 & 16 & 14 & 6,49 \\
\hline VT 2 Technology & 72 & 64 & 75 & 14 & 16 & 8,07 \\
\hline VT 2 Economics & 63 & 57 & 75 & 15 & 17 & 7,34 \\
\hline VT 2 Health Care & 70 & 64 & 71 & 18 & 18 & 7,13 \\
\hline VT 3 & 66 & 66 & 71 & 11 & 12 & 9,04 \\
\hline VT 3 Agriculture & 58 & 56 & 58 & 9 & 13 & 8,40 \\
\hline VT 3 Technology & 63 & 74 & 72 & 12 & 14 & 10,03 \\
\hline VT 3 Economics & 57 & 53 & 66 & 16 & 16 & 8,24 \\
\hline VT 3 Health Care & 76 & 76 & 80 & 5 & 7 & 9,61 \\
\hline VT 3 Behaviour \& Society & 72 & 73 & 72 & 10 & 14 & 9,31 \\
\hline VT 4 & 74 & 67 & 69 & 7 & 11 & 9,82 \\
\hline VT 4 Agriculture & 72 & 69 & 69 & 7 & 9 & 8,72 \\
\hline VT 4 Technology & 76 & 72 & 72 & 7 & 10 & 10,30 \\
\hline VT 4 Economics & 70 & 55 & 64 & 10 & 12 & 8,93 \\
\hline VT 4 Health Care & 85 & 80 & 78 & 4 & 8 & 10,97 \\
\hline VT 4 Behaviour \& Society & 69 & 63 & 62 & 7 & 12 & 9,69 \\
\hline DR & 72 & 79 & 83 & 4 & 5 & 11,97 \\
\hline DR 1 & 47 & 48 & 73 & 9 & 7 & 10,26 \\
\hline DR 2 & 71 & 73 & 81 & 5 & 7 & 10,36 \\
\hline DR 2 Agriculture & 68 & 71 & 83 & 7 & 6 & 10,23 \\
\hline DR 2 Technology & 70 & 75 & 81 & 4 & 4 & 10,43 \\
\hline DR 2 Economics & 68 & 64 & 80 & 9 & 12 & 9,17 \\
\hline DR 2 Health Care & 76 & 80 & 86 & 4 & 7 & 11,91 \\
\hline DR3 & 71 & 85 & 87 & 3 & 4 & 12,51 \\
\hline DR 3 Agriculture & 70 & 81 & 84 & 3 & 3 & 12,10 \\
\hline DR 3 Technology & 67 & 87 & 84 & 2 & 3 & 12,82 \\
\hline DR 3 Economics & 57 & 69 & 82 & 4 & 6 & 10,66 \\
\hline DR 3 Health Care & 83 & 94 & 92 & 2 & 2 & 13,45 \\
\hline DR 3 Behaviour \& Society & 87 & 88 & 86 & 6 & 10 & 13,16 \\
\hline DR 4 & 85 & 86 & 87 & 2 & 3 & 13,94 \\
\hline DR 4 Agriculture & 73 & 72 & 94 & 0 & 0 & 11,88 \\
\hline DR 4 Technology & 81 & 90 & 87 & 2 & 2 & 14,47 \\
\hline DR 4 Economics & 72 & 70 & 78 & 3 & 3 & 11,82 \\
\hline DR 4 Health Care & 94 & 96 & 88 & 1 & 2 & 14,94 \\
\hline DR 4 Behaviour \& Society & 89 & 84 & 78 & 6 & 11 & 14,48 \\
\hline
\end{tabular}




\section{Labour market}

At least at own level Own/related domain Match sufficient/ Unemployed Entry unemployment Gross hourly wages

(\%) $\operatorname{good}(\%)$

(\%)

$>3$ months $(\%)$

(euro)

HVE

HVE Agriculture

HVE Technology

77
79
85
80
81
55
89
67

75
74
81
66
88
76
90
62

72
74
75
67
81
68
84
69

$6 \quad 18$

$18 \quad 13,31$

HVE Economics

$\begin{array}{ll}8 & 21 \\ 6 & 16\end{array}$

21

HVE Health Care

HVE Behaviour \& Society

HVE Education

HVE Language \& Culture

69

73

76

12,90

2013,10

$3 \quad 17 \quad 14,72$

Total'

= inclusive PSVE

Source: ROA (SIS) 


\section{Unemployment trend}

$\begin{array}{lccccccccccc} & 2004 & 2005 & 2006 & 2007 & 2008 & 2009 & 2010 & 2011 & 2012 & 2013 & 2014 \\ \text { SVE-VT 1/2 } & 23 & 19 & 11 & 8 & 8 & 12 & 12 & 16 & 16 & 21 & 22 \\ \text { SVE-VT 3/4 } & 8 & 6 & 5 & 2 & 3 & 5 & 4 & 6 & 8 & 10 & 10 \\ \text { SVE-DR 1/2 } & 5 & 6 & 3 & 3 & 1 & 4 & 4 & 5 & 4 & 6 & 7 \\ \text { SVE-DR 3/4 } & 4 & 2 & 2 & 1 & 1 & 2 & 2 & 2 & 2 & 3 & 5 \\ \text { HVE } & 5 & 4 & 4 & 3 & 3 & 5 & 5 & 6 & 8 & 8 & 7\end{array}$

$-:$ not available

Note: The year is the year of the survey. In 2012, respondents came from the 2010-2011 survey.

Comments: In the 2000-2002 surveys, this concerns Lower Secondary General Education (LGSE)/Initial Professional Education (IPE) schoolleavers. From the 2003 survey onwards these are PSVE school-leavers. 


\section{School-leaver Information System}

\section{A publicly accessible data source}

General

The subsidies provided by the (Dutch) Ministry of Education, Culture and Science, the Ministry of Economic Affairs, and the Ministry of Social Affairs and Employment, enable the basic facilities (data collection, technical data management, and general methods and model studies). The data sets are freely accessible and thus enable a wide range of strategic research, from Ph.D. theses and academic policyrelevant articles, to national policy reports. The annual data sets from the School-leaver Information System are available through www.dans.knaw.nl. Researchers can also ask the Research Centre for Education and the Labour Market for a trend set in English (1998 - 2015 surveys) free of charge. For support in the use of the data sets, ROA researchers can be reached through secretary-roa-sbe@maastrichtuniversity.nl

Figures from the School-leaver Information System were recently used for, among others: ${ }^{\mathrm{I}}$

- Studiekeuze 123 (Study Selection) website;

- Studie in cijfers (Education in Figures);

- Keuzegids MBO (SVE Course Selection Guide), Keuzegids HBO (HVE Course Selection Guide);

- Onderwijs in Cijfers (Education in Figures) by the Ministry of Education, Culture and Science

- Dutch Inspectorate of Education: De staat van het onderwijs - onderwijsverslag (The State of Education - a report);

- Dutch Inspectorate of Education: Beginnende leraren kijken terug, deel I: de pabo (Junior Teachers Looking Back, Part I: Teacher Training College)

- Dutch Inspectorate of Education: Beginnende leraren kijken terug, deel 2: de pabo (Junior Teachers Looking Back, Part 2: Second-Degree Teacher Training)

- SEO/ECBO/ROA: Klaar voor de groei (Ready for Growth): Monitor uitrol Associate degree (Associate Degree Rollout Monitor)

- $\mathrm{MBO}$ raad (SVE Council): Feiten en cijfers (Facts and Figures);

- ECBO: Het Nederlandse onderwijs geketend (Dutch Education Chained): Doorstroom in en tussen vo en mbo (Moving from SE to SVE);

- ECBO: De kleur van het middelbaar beroepsonderwijs (The Colour of Secondary Vocational Education): Een overzichtsstudie naar allochtonen in het mbo (An Overview of Immigrants in SVE);
- Innovation Platform: Kennis en Innovatie Agenda $201 \mathrm{I}-2 \mathrm{O} 20$ (Knowledge and Innovation Agenda 20OI - 2020);

- SCP, Annual Integration Report, 2013.

Website Kerncijfers Schoolverlatersonderzoeken (Key Figures from the School-leaver Surveys website):

https://roastatistics.maastrichtuniversity.nI/SISOnline/Home. aspx

The Key Figures from the School-leaver Surveys website (https://roastatistics.maastrichtuniversity.nl/SISOnline/ Home.aspx) contains long-term national statistics on qualified school-leavers from initial education in the Netherlands. The figures are based on ROA's school-leaver surveys and relate to those who successfully completed a course in GSE, PSVE, SVE and Higher Education. The key figures presented provide insight in the courses completed, subsequent education and school-leavers' labour market entry.

The website can be consulted from two different perspectives: by educational classification and by key indicators. The educational perspective shows all key figures for a particular educational classification. Selections that can be made include educational levels, educational sectors and individual courses. There is also an option to select fulltime, part-time or dual education programmes. The indicator perspective shows the information for a single indicator for all education levels, sectors or courses. Both in the menu and in the overview tables, the key indicators have been divided into five categories:

- general background characteristics;

- course completed;

- opinion on the course completed;

- characteristics of subsequent education;

- labour marker indicators and job characteristics.

Each time, the figures shown represent the five most recent survey years and they are updated annually around the time of publication of the national 'School-leavers between Education and the Labour Market' report.

The website also provides detailed information on the methodological approach of the School-leaver Information System (SIS) and an account of the response. 


\section{Imprint}

(c) Research Centre for Education and the Labour Market (ROA). Nothing in this publication may be duplicated in any way without prior written permission from ROA's director.

Research Centre for Education and the Labour Market Maastricht University

School of Business and Economics

secretary-roa-sbe@maastrichtuniversity.nl

www.roa.nl

Layout

ROA Secretariat, Maastricht

November 2016 
Researchcentrum voor Onderwijs en Arbeidsmarkt

Postbus 616

6200 MD Maastricht

$\mathrm{T}+31433883647$

F +31 433884914

secretary-roa-sbe@maastrichtuniversity.nl

www.roa.nl

Maastricht University

School of Business and Economics 